\title{
Imaginárne domoviny: vymiestnenie v tvorbe Salmana Rushdieho
}

\author{
Monika Metyková
}

Táto stat' pojednáva o špecifickej forme vymiestnenia, exile, v diele anglo-indického spisovatel'a Salmana Rushdieho. Rushdie sa zarad'uje medzi predstavitel'ov magického realizmu, hlavnými témami jeho beletristickej i esejistickej tvorby sú migrácia, exil, zakorenenost' a preloženost' (,translatedness“'). Rushdieho prípad v dôsledku kontroverzie, ktorú vyvolal jeho román Satanské verše, znázorňuje nielen reflexiu žitej skúsenosti exilu v beletristickej a esejistickej forme, ale naviac ilustruje to, že ,v úsilí mediácie medzi kultúrami, jazykmi a spoločnost’ami je vždy prítomné nebezpečenstvo nesprávneho prekladu, zmätku a strachu“ (Bhabha cit. in Robins 1999: 16).

Rushdie sa narodil 19. júna 1947, v roku, ked’ India získala nezávislost', v moslimskej rodine v Bombaji. V Bombaji navštevoval anglickú misijnú školu, Cathedral School, a vo veku štrnástich rokov začal študovat' na Rugby School v Anglicku. V roku 1964 sa jeho rodina odst'ahovala do Karáči v Pakistane. O rok neskôr emigroval do Vel'kej Británie, kde študoval dejiny na King's College v Cambridgei. Svoj prvý román, Grimus, vydal v roku 1975. Nasledovali Deti polnoci (Midnight's Children) v 1981, Hanba (Shame) v roku 1983, Satanské verše (The Satanic Verses) v 1988, Maurov posledný vzdych (The Moor's Last Sigh) v roku 1995, Zem pod jej nohami (The Ground Beneath Her Feet) v 1999. Najnovším je jeho román Bes (Fury), ktorý bol publikovaný v roku 2001. Rushdieho esejistická tvorba zahrňuje zbierku esejí a recenzií s názvom Imaginárne domoviny (Imaginary Homelands) vydanej v roku 1991.

V románe Satanské verše charakterizuje Rushdie identitu exulantov nasledujúcim spôsobom:

Kým je? Exulantom. Nesmieme si ten pojem pliest', nesmieme dovolit', aby sa stotožnil so všetkými ostatnými, ktorými sa l’udia oháňajú: emigrant, expatriot, utečenec, imigrant, ticho, prefíkanost'. Exil je snom o slávnom návrate. Exil je víziou o revolúcii, Elbou, nie Svätou Helenou. Exil predstavuje nekonečný paradox: hl'adíme vpred tak, že sa vždy obraciame do minulosti. Exulant je lopta vyhodená vysoko do vzduchu. Visí tam, zmrazený v čase, preložený („translated“) do fotografie. Bola mu odňatá možnost' pohybu, nemožne visí nad svojou rodnou hrudou, čaká na nevyhnutný moment, ked' sa fotografia začne hýbat' a zem opät’ získa to, čo jej patrí. [...] Domovom exulanta je prenajatý byt. Je to čakáren̆, fotografia, vzduch.

(1992a: 205)

Rushdie tu načrtol otázky, ktoré sú kl’účové pre túto stat'. Predovšetkým Rushdie trvá na jasnom rozlíšení medzi rôznymi stavmi a identitami, ktoré plynú zo situácie migrácie.

Sociální studia. Fakulta sociálních studií Masarykovy univerzity v Brně, 2/2004. S. 71-78. ISSN 1214-813X.

Táto stat’ je skrátenou a prepracovanou verziou článku „Imaginary Homelands: Exile in Salman Rushdie's Fiction and Non-Fiction“ (Kalaga a Rachwał 2001). Všetky preklady z angličtiny do slovenčiny boli prevedené autorkou. 
Podobným spôsobom Edward Said, palestínsky exulant, zdôrazňuje extrémny charakter exilu v porovnaní s inými formami vymiestnenia. ${ }^{1}$ Úryvok tiež poukazuje na množstvo čŕt, ktoré sú exilu vlastné. Jedná sa o časové a priestorové charakteristiky identity exulantov, ich „,preloženost"“ (,translatedness") a vykorenenost'.

$\mathrm{K}$ lepšiemu pochopeniu časového a priestorového vymedzenia identity migrantov v Rushdieho beletristickej a esejistickej tvorbe načrtnem niekol'ko aspektov identity a ich chápanie v sociologickej a kulturologickej perspektíve. V dôsledku migrácie vel'kých populácií v priebehu dlhodobého trvania imperializmu a kolonializmu (nesmieme zabúdat', že Rushdieho žitá skúsenost' aj tvorba boli zásadne ovplyvnené migráciou a postkoloniálnymi zmenami odohrávajúcimi sa na indickom subkontinente) sa zmenili priestorové a kultúrne hranice. Kým koloniálne rozdelenie sveta viac menej udržalo „Druhých“ v bezpečnej vzdialenosti od „Nás“, v súčasnom svete sa už „Druhí” nenachádzajú na periférii európskeho priestoru, ale tvoria súčast' (bývalého) „koloniálneho centra“, v západných mestách žijú svetové kultúry v priamom kontakte (Robins 1999: 21). Migrácia však nemení len charakter priestoru ako takého (napríklad kompresia času a priestoru), ${ }^{2} \mathrm{v}$ jej dôsledku sa zároveň transformujú priestory, $\mathrm{v}$ ktorých existujú identity, mení sa chápanie sveta. Ako aktéri migrácie nadobúdame novú orientačnú skúsenost', pocit'ujeme dezorientáciu, zist'ujeme, že identity môžu byt' zakotvené alebo vykorenené.

Pre Rushdieho tvorbu (a zároveň pre vlastný tvorivý proces), ako ukážem v d’alšom, je klúčcová komplexná identita migrantov. Identita migrantov má určité špecifické rysy, nesmieme ale zabúdat', že komplexnost' charakterizuje identitu ako takú, slovami Declana Kiberda: „,identita je zriedka jasná a daná, častejšie je záležitost'ou vyjednávania a výmeny“ (1995: 1). Vo vzt’ahu k identitám v postmodernom svete sa často píše o narastajúcej flexibilite a fluidite, ktore sú dokonca považované za nevyhnutné predpoklady vyrovnávania sa s realitou postmoderného sveta. Podl’a Zygmunta Baumana je „moderným ,problémom identity " predovšetkým, ako identitu vytvorit' a udržat' ju celistvou a trvalou, postmoderným ,problémom identity“ je predovšetkým, ako sa vyhnút’ stálosti a ponechat' si všetky možnosti otvorenými““ (1996: 18). Vo svetle Baumanovho argumentu môžeme exil chápat’ ako životnú stratégiu, ktorá poskytuje nástroje na prežitie $\mathrm{v}$ postmodernom svete práve kvôli jeho nesúvislej (diskontinuálnej) povahe. Na druhej strane je možné rovnako presvedčivo tvrdit', že exil zásadným spôsobom obmedzuje výber životných stratégií a identít a môžeme ho teda považovat' za inherentne deštruktívny.

Priestorové a časové zakotvenie identity je rovnako dôležité ako jej kolektívne zakotvenie. Migranti nepredstavujú len jednotlivcov, sú zároveň predstavitel'mi (inej) skupiny, kultúry. Podl’a Bhabhu hybridný diskurz, ktorý vzniká v dôsledku migrácie, zohráva úlohu v zvláštnom vyjednávaní medzi kultúrami. „Takéto vyjednávanie nepredstavuje asimiláciu ani kolaboráciu. Umožňuje vznik ,intersticiálnej‘ (vklinenej) subjektivity, ktorá odmieta binárnu reprezentáciu sociálneho antagonizmu. Takéto hybridné subjektivity použivajú parciálnu kultúru, z ktorej pochádzajú, $\mathrm{k}$ vytvoreniu vízie komunity a verzií historickej pamäte, ktoré dodávajú minoritnému postaveniu, v ktorom sa nachádzajú, formu výkladu, predstavujú vonkajšok vnútra - čast’ v celku“ (1996: 58). Podobnú myšlienku sformuloval v roku 1908 Georg Simmel: 
Hoci je neorganicky pripojený ku skupine, je cudzinec („stranger“) organickým členom skupiny. Uniformný život skupiny zahrňuje zvláštny stav tohto elementu. Jedná sa iba o to, že nevieme, akým spôsobom vyjadrit' zvláštnu jednotu tohto postavenia inak ako tvrdením, že zahrňuje určitú blízkost' a odstup („distance“). Hoci určitá miera oboch je charakteristická pre každý vzt'ah, zvláštny podiel a vzájomné napätie určujú osobitný, formálny vzt’ah s „cudzincom“.

Životná stratégia vymiestnených osôb - „cudzincov“ (úvodzovky sú v tomto prípade zámerné, pretože títo cudzinci nám nie sú úplne cudzí) - často nepredstavujú preferovanú - ale práve naopak vynútenú - životnú stratégiu. Vo svojich úvahách a pri čítaníi Rushdieho tvorby nesmieme zabúdat', že milióny vymiestnených osôb, dislokovaných kultúr a rozbitých komunít musia žit' minimálne s dvomi identitami, v dvoch jazykoch,

sú produktmi hybridných kultúr. Tento koncept hybridity je vel'mi rozdielny od starého internacionálneho vel'kého rozprávania, od povrchnosti staromódneho pluralizmu, pri ktorom nie sú prekročené hranice a tiež od módneho nomádskeho cestovania prítomného v postmoderných či zjednodušujúcich verziách globálnej homogenizácie - jedna prekliata vec za druhou alebo rozdiel, ktorý neučiní žiadny rozdiel. Títo „hybridi“ zachovávajú silné putá a identifikujú sa s tradíciami a miestami svojho „pôvodu“. Ale nemajú žiadne ilúzie ohl’adne „návratu“ do minulosti.

(Hall 1999: 43)

$\mathrm{Na}$ identitu exulantov teda nevplýva iba odtrhnutie od miesta pôvodu, ale tiež odlišné vnímanie času ako v prípade „umiestnených“ identít. Exulanti sú vždy mimo čas a miesto, pretože je im odmietaný neobmedzený prístup k ich pôvodným a tiež k osvojeným domovinám. Exulanti, a migranti vo všeobecnosti, sú tiez zbavení spojenia s vlastnou minulost'ou. Vo svojom románe Hanba (Shame) Rushdie píše:

Všetci migranti zanechávajú za sebou svoju minulost', aj ked' sa ju niektorí snažia zabalit' do uzlíčkov a krabíc. Cestou sa ale z prechovávaných spomienkových predmetov a starých fotografíi niečo vytratí, až ich nakoniec nepoznávajú ani ich vlastní majitelia, pretože osudom migrantov je, aby boli obraní o dejiny, aby stáli nahí uprostred opovržlivých pohl'adov neznámych, na ktorých vidia drahé šaty, brokát kontinuity a obočie spolupatričnosti.

Exulanti zostávajú bez dejín, to však neznamená, že sa úplne vzdávajú svojej minulosti, platí skôr, že sa snažia znovu nadobudnút' minulost' v procese jej re-konštrukcie, v ktorom sa spoliehajú na pamät', na vzpomienky a tiež na predstavivost’ a pocity. ${ }^{3}$ Rushdie sa týmto javom zaoberá napríklad v románe Hanba: „Čo sa týka mňa, ja som, podobne ako všetci migranti, fantasta. Staviam imaginárne krajiny a snažím sa ich preniest' do tých, ktoré existujú. Aj ja stojím tvárou v tvár otázke dejín: čo mám zachovat', čoho sa mám zbavit', ako mám zachovat' to, čo ma pamät' núti odvrhnút', ako sa mám vysporiadat' so zmenami. “" Inou otázkou je, či sa znovunadobudnutie minulosti môže zvrtnút' v hrozbu. Navzdory roli, ktorú zohrávajú historické výklady a mýty v konštrukcii kolektívnych identít (vrátane nacionalistických a rasistických konštrukcií), Bhabha trvá na ich potenciálne prínosnej roli:

Významnost’ spätného pôsobenia leží v umožnení prepísania, znovuaktivovania, premiestnenia, znovuoznačenia minulosti. Dôležitejšie je, že spätné pôsobenie zaväzuje naše chápanie minulosti 
a našu opätovnú interpretáciu budúcnosti k etike „prežitia“, ktorá nám umožňuje prepracovat’ sa súčasnost'ou. A takéto prepracovanie sa nás oslobodzuje od determinizmu historickej nevyhnutnosti, od opakovania bez jediného rozdielu.

(1996: 59, pôvodná kurzíva)

Jedným z ústredných charakteristík identity migrantov, a tiež Rushdieho tvorby, je otázka preloženosti (,translatedness“"). Ako som už naznačila, jedná sa de facto o črtu, ktorá charakterizuje postmoderný, postkoloniálny svet ako taký. „Kým sme kedysi mohli verit’ v útechu a kontinuitu, ktoré poskytovala Tradícia, dnes musíme čelit’ zodpovednosti, ktorá plynie z Prekladu kultúry“ (Bhabha cit. in Robins 1999). Exulanti so sebou prinášajú úlomky svojej kultúry do novej domoviny, niektoré z nich prispôsobia zmeneným podmienkam a vytvárajú tak ,zvláštne typy kultúrneho pochopenia a kultúrneho konfliktu“ (T. S. Eliot cit. in Bhabha 1996: 54). Kultúry sú ,preložené“ a prispôsobené podobným spôsobom ako texty, niektoré ich črty vymiznú, iné, ako tvrdí Rushdie, sa môžu pridat'. „Ja sám som tiež preloženým človekom (,translated man'). Prerodil som sa. Vo všeobecnosti sa verí, že v procese prekladu sa niečo stratí, ja lipnem na tom, [...] že je tiež možné niečo získat"، (1995a: 29).

Črty exulantskej skúsenosti, ktorými som sa doteraz zaoberala, by sa dali zhrnút' pod dvomi hlavičkami: zakorenenost' a spolupatričnost'. Podl'a Simone Weil „mat' svoje korene je pravdepodobne najdôležitejšou a najmenej uznanou potrebou l'udskej duše“ (cit. in Said 1984: 169). Exulanti sa nachádzajú v stave vykorenenia, sú naraz zasvätení aj nezasvätení („outsider and insider"), vznášajú sa niekde medzi „nami“ a „nimi“, v stave nespolupatričnosti, sú pre nás cudzí a zároveň blízki, ako píše o neznámom (,the stranger“) Georg Simmel:

On je takpovediac potenciálnym tulákom: aj ked' sa ešte nepohol d’alej, ešte sa úplne nevzdal slobody prichádzat' a odchádzat'. Je ukotvený v rámci určitej priestorovej skupiny, či skupiny, ktorej hranice sú podobné hraniciam priestorovým. Ale jeho pozícia v tejto skupine je v zásade určená skutočnost'ou, že do nej nepatril od začiatku, že do nej vnáša kvality, ktoré nevychádzajú a nemôžu vychádzat’ zo skupiny samotnej.

(1950: 402)

Hoci Rushdie pripúšt’a existenciu zakorenenosti, rozhodne zamieta mýty s ňou spojené:

Porovnávam gravitáciu so spolupatričnost'ou. Oba javy sú jasne pozorovatel'né, moje nohy stoja na zemi a nikdy som nebol väčšmi nazlostený než v deň, ked’ mi otec oznámil, že predal dom, v ktorom som vyrastal v Bombaji. Ani jeden z týchto javov však nechápeme. Poznáme silu gravitácie, ale nie jej pôvod. A k tomu, aby sme vysvetlili, prečo sme viazaní na svoje rodisko, predstierame, že sme stromy a hovoríme o koreňoch. Pozrite sa pod svoje nohy. Nenájdete tam uzlovitú vegetáciu klíčiacu z vašich chodidiel. Občas si myslím, že korene predstavujú konzervatívny mýtus, ktorý má za úlohu nás držat' na našom mieste. Protiklady mýtov gravitácie a spolupatričnosti majú rovnaké meno: únik. ${ }^{5}[\ldots]$ Letiet' a utiect': oboje predstavujú spôsoby hl'adania slobody.

(1995a: 86)

Exil a iné formy vymiestnenia, ako som už naznačila, predstavujú zvláštny stav, ktorý umožňuje (správnejšie by možno bolo napísat' „vyžaduje“) byt' naraz súčast'ou dvoch kultúr a v tom istom čase si od oboch zachovat' odstup. Exil sa môže stat' skúsenost'ou, ktorá obohacuje práve kvôli simultánnemu žitiu dvoch (či viacerých) identít, kultúr, pohl'adov na svet, spôsobov interpretácie reality. Podl'a Edwarda Saida, 
...táto pluralita videnia umožňuje vedomie simultánnych dimenzií, vedomie, ktoré (použijem hudobný výraz) je kontrapunktné. V prípade exulanta sa každodenné návyky, výrazy či činnosti v novom prostredí odohrávajú na pozadí spomienok na podobné návyky v inom prostredí. Takže nové aj staré prostredie sú obe živé, súčasné, odohrávajú sa kontrapunktne. S týmto druhom vnímania sa spája zvláštne potešenie, hlavne, ak si exulant uvedomuje iné kontrapunktné porovnávania, ktoré oslabujú ortodoxné názory a podporujú uznanlivé pochopenie. V tom, že niekto koná, ako keby bol doma kdekol'vek sa práve ocitol, tiež nachádzame zvláštny pocit úspechu.

(1984: 171)

Kontrapunktné alebo stereoskopické videnie, aby som použila Saidov aj Rushdieho termín pre rovnaký jav, však predstavuje maximum toho, čo môže exulant dosiahnut' a nedosahuje ho vždy.

Aj vo svojej beletristickej tvorbe Rushdie zdôrazňuje prínos dvojitého videnia, preloženosti a re-konštrukcie minulosti, napríklad v románe Hanba charakteristickým spôsobom vyzdvihuje pozitívny výkon migranta, ktorý nemôžu dosiahnut' l'udia s ustálenými identitami. „Mám takú teóriu, podl'a ktorej sme my, mohadžíri (migranti), vystavení tol'kej nenávisti kvôli tomu, že sme porazili silu gravitácie. Urobili sme to, po čom všetci muži snia odnepamäti, to, čo závidia vtákom, znamená to, že my sme leteli“ (1995a: 85). Ovšem by bolo zjednodušením tvrdit', že Rushdie chápe migráciu ako bezvýhradne pozitívnu skúsenost'. Jedná sa o komplikovanejší a menej jednoznačný prípad. Vezmime si napríklad Rushdieho zbierku poviedok Východ, Západ. Na obálke českého vydania je uvedený Rushdieho výrok: „Nejdůležitější částí názvu knihy Východ, Západ je ona čárka. Zdá se mi, že tou čárkou jsem právě já." Rushdieho hrdinka Mary z poviedky „Uvaděč“ je stelesnením čiarky. Pracuje ako ayah (pestúnka) v indickej rodine, ktorá sa prest’ahovala z Bombaja do Londýna a je zmietaná medzi východom a západom. V prípade Mary sa otázka spolupatričnosti a zakorenenia prejaví neočakávaným spôsobom, vo forme záhadnej srdečnej choroby, ktorá zmizne po jej návrate do Bombaja. Rushdie píše:

Takže to byla Anglie, co jí tížilo, lámala jí srdce tím, že nebyla Indií. Londýn ji ničil tím, že nebyl Bombají. A co Mišmaš? ř́kal jsem si. Ničí ji uvaděč také, protože už to není on? Nebo je její srdce, spoutané dvěma odlišnými láskami, taženo zároveň na východ a na západ, takže řehtá a vzpíná se jako ti filmoví koně, kterými Clark Gable cloumal na jednu stranu a Montgomery Clift na druhou, a ona si uvědomuje, že chce-li přežít, bude si muset vybrat?

(1997: 164)

Po odchode Mary otec rozhodne, že rodina odcestuje do Pakistanu a 17-ročný syn zostane v Anglicku. Tiež on radikálne zmení svoj život:

Toho roku jsem se stal britským občanem. [...] A cestovní pas mě v mnoha ohledech osvobodil. Umožnil mi jezdit, kam se mi zlíbilo, a rozhodovat se tak, jak by si byl otec nepřál. Ale i já mám na krku provazy, mám je dodnes, cloumají se mnou sem a tam, na východ i na západ, smyčky se utahují a přikazují: vyber si, vyber. Vzpínám se, frkám, řehtám, stavím se na zadní, kopu. Provazy, mezi vámi si nevyberu. Lasa, smyčky, nevolím si z vás ani jedno, a přitom obojí. Slyšíte? Odmítám si vybrat.

Podl'a Rushdieho teda migrácia navzdory rozvratnému či dokonca život ohrozujúcemu vplyvu poskytuje migrantovi zvláštny druh pohl'adu, ktorý Rushdie premieta do postáv vo 
svojej beletrii. Naviac, tento druh chápania je pre Rushdieho-spisovatel’a životne doležitým. V eseji nazvanej „Imaginárne domoviny“ z roku 1992 Rushdie píše o situácii spisovatel’ov, ktorí zdiel'ajú podobný osud:

Naša identita je naraz plurálna a parciálna. Niekedy máme pocit, že stojíme obkročmo vo dvoch kultúrach, inokedy, že padáme medzi dve stoličky. Akokolvek nejasný a premenlivý je terén, na ktorom sa pohybujeme, pre spisovatela nie je neplodným územím. Ak je úlohou literatúry nachádzat' nové zorné uhly, z ktorých chápat' realitu, tak nám opät' naša odtrhnutost', naša vzdialená zemepisná perspektíva, môže poskytnút takéto uhly. Je tiež možné, že si to jednoducho musíme mysliet' k tomu, aby sme robili svoju prácu.

(1992b: 15)

\section{Rushdie tento argument rozvíja d’alej:}

Je možné tvrdit', že minulost' je krajinou, z ktorej sme všetci emigrovali, že jej strata je súčast'ou našej spoločnej l'udskosti. Mne sa zdá, že je to zjavne pravdivé tvrdenie, podotýkam však, že spisovatel', ktorý je mimo svojej krajiny a dokonca mimo svoj rodný jazyk, pocit'uje túto stratu v intenzívnejšej podobe. [...] To mu môže umožnit' vypovedat' náležite a konkrétne o predmete, ktorý má všeobecnú významnost' a prít’ažlivost'.

(1992b: 12)

Rushdie prežil väššinu svojho dospelého života v anglosaskom prostredí, väčšinu svojej beletristickej tvorby však venoval Indii. Dilemy, ktoré vyplynuli z tejto skutočnosti zhrnul $\mathrm{v}$ jednej zo svojich esejí:

Čo znamená byt' „Indom“ mimo Indie? Ako môžeme zachovat' kultúru bez toho, aby skostnatela? Akým spôsobom môžeme pojednávat' o zmene v nás samých a v našej komunite bez toho, abysme zdanlivo nenahrávali našim rasovým nepriatel'om? Aké sú dôsledky, duševné i praktické, odmietnutia akýchkol'vek ústupkov voči západným myšlienkam a zvyklostiam? Aké sú dôsledky osvojenia si týchto myšlienok a zvyklostí a odvrátenia sa od tých, ktoré sme si so sebou priniesli? Všetky tieto otázky sú jedinou existenciálnou otázkou: Ako máme žit’ na svete?

(1992b: 18)

Gayatri Spivak, vplyvná intelektuálka indického pôvodu žijúca v USA, popisuje svoju skúsenost' podobne:

Usadenie sa v Spojených štátoch nebolo v žiadnom okamihu premyslenou vol'bou, učinením skutočného rozhodnutia. [...] Indiu som opustila bez akejkolvek skúsenosti toho, aké je žit’ a pracovat' v Indii. Ponechala som si občianstvo, čím d’alej tým viac sa do tejto situácie vžívam. Mám dve tváre. Nie som exulantkou. Nie som migrantkou. Som kritičkou neokolonializmu, ktorá nosí zelenú kartu v Spojených štátoch. Vyjednávanie tejto pozície je obtiažne, pretože sa nemienim v Spojených štátoch marginalizovat' kvôli tomu, aby som si získala súcit l’udí, ktorí sú skutočne marginalizovaní.

Edward Said varuje pred romantickým a zjednodušeným chápaním exilu. Tvrdí, že „najprv musíme dat' bokom Joycea a Nabokova a miesto nich sa zamýšlat' nad nespočetnými davmi, kvôli ktorým sa vytvorili agentúry Organizácie spojených národov“. Podl’a Saida, 
v merítku dvadsiateho storočia exil nie je pochopitel'ný ani esteticky ani humanisticky - prinajlepšom literatúra o exile objektivizuje trápenie a údel, ktorý väčšina l’udí nezažije na vlastnej koži. Považovat' exil, z ktorého táto literatúra čerpá, za humanisticky prínosný, znamená bagatelizovat' zmrzačenie, ktoré so sebou prináša, rany, ktoré zasadí, nemotu, ktorou exil reaguje na akúkolvvek snahu chápat' ho ako pre nás prospešný.

(1984: 160)

Rushdieho prvotná skúsenost' exulanta indického pôvodu žijúceho v Británii sa radikálne zmenila po publikácii Satanských veršov v roku 1988. Román vyvolal vlnu odporu, predovšetkým v moslimských krajinách. Dňa 14. februára 1989 Ajatolláh Chomejní uvalil na Rushdieho fatwu (trest smrti), na Rushdieho hlavu bola vypísaná odmena v hodnote milión amerických dolárov, ktorá bola v roku 1997 zdvojnásobená. V roku 1998 sa iránska vláda zaviazala nepodniknút žiadne kroky, ktoré by ohrozili Rushdieho život. Iránska vláda sa tiež dištancovala od odmeny, ktorá bola vypísaná na jeho hlavu a ktorú iránski náboženskí vodcovia medzičasom zvýšili na dva a pol milióna dolárov. V roku 2000 sa Rushdie prest’ahoval do New Yorku. Vzápätí po vydaní Satanských veršov sa Rushdie začal skrývat', paradoxne sa tak z jedného exilu dostal do exilu d'alšieho:

Nuž, či sa to Rushdiemu páči alebo nie, ešte stále zostáva stredobodom záujmu, pretože sa pervezne, surreálne, kafkovsky, stal živým stelesnením svojej tvorby. Bol uvrhnutý do d’alšieho exilu, dvojitého exilu, nielen zo svojho predošlého života anglo-indického spisovatel'a ${ }^{6}$ (a ateistu), študovaného v Cambridgei, žijúceho v Londýne. Pokial' existuje akákol'vek malá výhoda v jeho takmer šiestich rokoch izolácie, môže spočívat' v skutočnosti, že sa mohol dôkladnejšie oddat' exulantskému privilégiu $^{7}$ spomínania, znovu vynájdenia minulosti, vytvárania novej domoviny v próze.

(Blythe 1995)

Vo svojej tvorbe Salman Rushdie oslavuje kultúrny pluralizmus, migráciu, diverzitu a flexibilitu, darí sa mu nepovýšit' exil na inherentne užitočný stav. Rushdieho tvorba je napriek tragickému koncu mnohých jeho postáv na určitých rovinách oslavou diverzity a volaním po väčšej tolerancii voči rôznorodým životným stratégiám a identitám v spoločnostiach, ktoré výber identít značne obmedzujú. Slovami Zygmunta Baumana:

V konečnom dôsledku sa opätovne jedná o starú pravdu: každá spoločnost' obmedzuje rozsah životných stratégií, ktoré je možné si predstavit', a určuje tie, ktoré môžu byt' uplatnené. Ale druh spoločnosti, v ktorej žijeme, obmedzuje tú stratégiu (tie stratégie), ktoré kriticky a naliehavo spochybňujú jej vlastné princípy, a tým otvárajú cestu k novým stratégiám, ktoré sú v súčasnosti neprístupné kvôli ich neprijatel'nosti...

(1996: 35)

\section{Poznámky}

1 Či nesprávneho umiestnenia. Okrem termínu vymiestnenie (,displacement“) sa tiež používa termín nesprávne umiestnenie (,misplacement“).

2 V tejto súvislosti viz tiež Robinsovu topografiu siete alebo elektronickú geografiu (Robins 1999: 20).

3 Osobné i národné mytológie sa vytvárajú podobným spôsobom.

4 Írsky básnik Seamus Heaney, nositel' Nobelovej ceny za literatúru, vyjadril úlohu predstavivosti v nasledujúcich veršoch: „Whatever is given,/Can always be reimagined, however four-square,/ 
Plan-thick, hull-stupid and out of its time/It happens to be“ (1995: 200).

5 V originále „flight“, ktorý môžeme preložit’ ako „únik“, „let“, „útek“.

6 Jedným z následkov vyhlásenia fatwy je, že sa Rushdie obáva vycestovat’ do Indie kvôli možným extrémistickým nepokojom. V roku 1995 komentoval vydanie románu Maurov posledný vzdych: „Je celkom možné, že toto je posledný vel'ký román, ktorý môžem umiestnit' do Indie. Nechcem písat' knihy, ktoré nie sú zakotvené (are out-of-touch), sú nostalgické“ (Crichton 1995). Dej jeho najnovšieho románu Bes (z roku 2001) sa vskutku neodohráva v Indii, ale v New Yorku.

7 Jedná sa o ukážku „oslavného“ chápania exilu, pred ktorou varuje Edward Said.

\section{Literatura}

Bauman, Z. 1996. „From Pilgrim to Tourist - or A Short History of Identity.“ In S. Hall, P. du Gay (eds.) Questions of Cultural Identity, Londýn: Sage.

Bhabha, H. 1996. „Culture's-in-Between.“ In S. Hall, P. du Gay (eds.) Questions of Cultural Identity, London: Sage.

Blythe, W. 1995. „Salman Rushdie Goes Home.“ Esquire 122 (6).

Crichton, S. 1995. „Caught Between East and West, Rushdie Keeps On.“ Newsweek 125 (6).

Hall, S. 1999. „Culture, Community, Nation.“ In D. Boswell, J. Evans (eds.) Representing the Nation: A Reader, Londýn: Routledge.

Heaney, S. 1995. The Redress of Poetry: Oxford Lectures. Londýn: Faber \& Faber.

Kiberd, D. 1995. Inventing Ireland: The Literature of the Modern Nation. Londýn: Jonathan Cape.

Metyková, M. 2001. „Imaginary Homelands: Exile in Salman Rushdie's Fiction and Non-Fiction." In W. H. Kalaga, T. Rachwał (eds.) Exile:Displacements and Misplacements. Literary and Cultural Theory. Zväzok 11, Frankfurt: Peter Lang.

Robins, K. 1999. „Tradition and Translation: National Culture in Its Global Context.“ In D. Boswell, J. Evans (eds.) Representing the Nation: A Reader, Londýn: Routledge.

Rushdie, S. 1992a. The Satanic Verses. Dover, Delaware : The Consortium.

Rushdie, S. 1992b. Imaginary Homelands: Essays and Criticism 1981-1991. Londýn: Granta Books.

Rushdie, S. 1995a. Shame. Londýn: Vintage.

Rushdie, S. 1995b. East, West. Londýn: Vintage.

Rushdie, S. 1997. Východ, Západ. Praha: Labyrint.

Said, E. 1984. „Reflections on Exile.“ Granta 13.

Simmel, G. 1950. „The Stranger.“ In K. Wolff (ed. a prekl.) The Sociology of Georg Simmel, New York: Free Press.

Spivak, G. 1994. „Bonding in Difference.“ In A. Artega (ed.) An Other Tongue: Nation and Ethnicity in the Linguistic Borderlands, Durham a Londýn : Duke University Press.

\section{Autor}

Mgr. Monika Metyková MRes, MPhil je od roku 2000 študentkou doktorského programu sociológie na FSS MU v Brne. Vo svojej dizertácii sa venuje regulácii vysielania verejnej služby vo vybraných postkomunistických krajinách. V súčasnosti pôsobí ako Marie Currie Fellow na Dublin City University v Írsku, kde skúma vývoj írskej mediálnej politiky za posledných pätnást’ rokov. Kontaktný e-mail: metykova@fss.muni.cz 